\title{
Analgesia de Parto em Paciente com Tetralogia de Fallot Não Corrigida. Relato de Caso *
}

\section{Labour Analgesia in Parturient with Uncorrected Tetralogy of Fallot. Case Report}

\author{
Florentino Fernandes Mendes, TSA $^{1}$; Carlos Alberto T Farias $^{2}$; Daniel Segabinazzi ${ }^{3}$
}

\section{RESUMO}

Mendes FF, Farias CAT, Segabinazzi D - Analgesia de Parto em Paciente com Tetralogia de Fallot Não Corrigida. Relato de Caso

JUSTIFICATIVA E OBJETIVOS: Embora a tetralogia de Fallot seja a mais comum das cardiopatias congênitas cianóticas, as publicações nacionais, relacionando essa doença com a prática anestésica são escassas. O objetivo deste relato é apresentar um caso de analgesia de parto em paciente portadora de tetralogia de Fallot não corrigida e diagnosticada durante a gestação.

RELATO DO CASO: Paciente com 26 anos, $56 \mathrm{~kg}, 1,56 \mathrm{~m}$, idade gestacional 32 semanas e 5 dias, com diagnóstico de tetralogia de Fallot realizado durante a gestação. Internou em trabalho de parto. A conduta obstétrica foi a de parto via baixa, sendo realizada analgesia através de bloqueio peridural com bupivacaína a 0,125\% e fentanil $(100 \mu \mathrm{g})$ e colocação de cateter peridural. Após $1 \mathrm{~h} 30$ minutos do início da analgesia, ocorreu o nascimento. O peso do recém-nascido foi $1485 \mathrm{~g}$ e o índice de Apgar 6 e 8 no primeiro e no quinto minutos, respectivamente. A paciente permaneceu estável e sem alterações hemodinâmicas e/ou eletrocardiográficas.

CONCLUSÕES: A escolha da técnica anestésica é de fundamental importância no manuseio das pacientes com tetralogia de Fallot não corrigidas. Condições favoráveis do colo e boa dinâmica uterina, particularmente naquelas pacientes sem história de síncope, tornam-se imprescindíveis para uma boa indicação da analgesia de parto.

Unitermos: ANALGESIA, Parto; DOENÇAS, Cardíaca: tetralogia de Fallot; TÉCNICAS ANESTÉSICAS, Regional: peridural contínua

\footnotetext{
* Recebido da (Received from) Maternidade Mário Totta - Núcleo de Anestesia e Analgesia Obstétrica do Serviço de Anestesiologia da Santa Casa de Porto Alegre - CET/SBA FFFCMPA, Porto Alegre, RS

1. Chefe do Serviço de Anestesiologia da Santa Casa de Porto Alegre. Mestre em Farmacologia pela FFFCMPA. Doutor em Medicina pela FCMSCSP

2. Médico do Serviço de Anestesiologia da Santa Casa de Porto Alegre. Médico Anestesiologista do Grupo Hospitalar Conceição

3. $M E_{2}$ do CET/SBA da FFFCMPA
}

Apresentado (Submitted) em 03 de outubro de 2003

Aceito (Accepted) para publicação em 27 de setembro de 2004

Endereço para correspondência (Correspondence to)

Dr. Carlos Alberto T. Farias

Av. Arnaldo Bohrer, 184/23 Bairro Teresópolis

91720-130 Porto Alegre, RS

E-mail: carlostf@terra.com.br

(c) Sociedade Brasileira de Anestesiologia, 2005
SUMMARY

Mendes FF, Farias CAT, Segabinazzi D - Labour Analgesia in Parturient with Uncorrected Tetralogy of Fallot. Case Report

BACKGROUND AND OBJECTIVES: Although tetralogy of Fallot is the most common cyanotic congenital heart disease, national publications correlating this condition with anesthetic practice are scarce. This report aimed at presenting a case of labor epidural analgesia in a patient with uncorrected tetralogy of Fallot diagnosed during gestation.

CASE REPORT: Patient 26 years old, $1.54 \mathrm{~m}, 56 \mathrm{~kg}, 32$ weeks and 5 days of gestational age, who had been diagnosed with tetralogy of Fallot during gestation. Patient was admitted in labour. After obstetric evaluation and decision for natural birth, epidural analgesia was performed with $0.125 \%$ bupivacaine associated to $100 \mu \mathrm{g}$ fentanyl through a catheter. Patient gave birth 1 hour and 30 minutes after the procedure. The newborn weighed 1485 grams and had an Apgar score of 6 and 8 at one and five minutes, respectively. Patient remained stable, with no hemodynamic or ECG changes.

CONCLUSIONS: Selecting the appropriate anesthetic technique is extremely important when managing patients with uncorrected tetralogy of Fallot. Favorable uterine dynamics and cervical conditions, particularly in patients with no history of syncope, are critical findings for adequate labour analgesia indication.

Key Words: ANALGESIA, Labour; ANESTHETIC TECHNIQUES: Regional: epidural continuous; DISEASES, Cardiac: tetralogy of Fallot

\section{INTRODUÇÃO}

tetralogia de Fallot é uma cardiopatia congênita cianótiAca, caracterizada por obstrução à saída do ventrículo direito, hipertrofia ventricular direita, defeito no septo interventricular e transposição aórtica variável ${ }^{1,2}$. A obstrução à via de saída ventricular direita em muitos pacientes é devida à estenose infundibular. Em pelo menos $20 \%$ a $25 \%$ dos pacientes também há estenose da valva pulmonar e uma pequena percentagem tem algum elemento de estenose supravalvar. A obstrução infundibular está aumentada em situações de tônus simpático elevado (variável dinâmica); essa obstrução é a provável responsável pela cianose observada em muitos pacientes jovens ${ }^{3}$.

A combinação de obstrução à saída do ventrículo direito e a comunicação interventricular (CIV) resulta na ejeção de sangue não-oxigenado do ventrículo direito e oxigenado através da aorta. O shunt direito-esquerdo é que determina o grau de hipoxemia e, conseqüentemente, a gravidade da doença. Esta varia em função de componentes fixos: grau de obstrução do ventrículo direito, grau de dextroposição da aorta, ta- 
manho da CIV - e variáveis - resistência vascular sistêmica (RVS) e pulmonar (RVP), obstrução infundibular, retorno venoso e contratilidade miocárdica ${ }^{4}$. Eventos com aumento da RVP, como acidose e aumento de pressão nas vias aéreas devem ser evitados ${ }^{5}$.

A manutenção dos componentes variáveis é ponto essencial no manuseio anestésico de pacientes com a doença não corrigida, já que são os principais determinantes do equilíbrio hemodinâmico desses indivíduos.

O objetivo deste relato é apresentar um caso de analgesia de parto em paciente portadora de tetralogia de Fallot não corrigida e diagnosticada durante a gestação, relacionando os cuidados no manuseio anestésico desta doença.

\section{RELATO DO CASO}

Paciente com 26 anos, 56 kg, 1,56 m, primigesta, idade gestacional de 32 semanas e 5 dias, em trabalho de parto, com dinâmica uterina de 3 contrações em 10 minutos e com $4 \mathrm{~cm}$ de dilatação do colo uterino. Durante o pré-natal foi auscultado importante sopro cardíaco, sendo encaminhada para pré-natal em hospital especializado onde foi diagnosticada a tetralogia de Fallot. Negava ter conhecimento prévio da doença. Referia dispnéia leve e cianose de extremidades que se agravaram com o decorrer da gestação, e se associaram à dor precordial aos médios esforços, entretanto não incapacitantes.

Durante a avaliação pré-anestésica apresentava-se com cianose central e de extremidades, baqueteamento digital. Negava alergias, cirurgias prévias e uso de medicações. O exame cardiotocográfico e a ecocardiografia fetal eram normais.

A ecocardiografia materna, realizada com 27 semanas de gestação revelou levocardia, arco aórtico à esquerda, conexão AV concordante e modo normal, conexão ventrículo-arterial concordante e modo de conexão normal. Apresentava como defeito associado ampla CIV subaórtica que provocava desvio anterior e superior do septo interventricular, sugerindo tetralogia de Fallot. Ventrículos e átrios com dimensões, espessura e movimentação normal. O eletrocardiograma apresentava inversão da onda T ântero-septal.

A conduta obstétrica foi a de parto por via baixa com analgesia. Amonitorização consistiu de oxímetro de pulso que oscilava em $89 \%$ a $78 \%$ de acordo com a presença ou não de dinâmica uterina, eletrocardioscopia que mostrava ritmo regular e inversão de onda T e pressão arterial não-invasiva, evidenciando níveis médios de $120 / 60 \mathrm{mmHg}$. Os escores de dorforam monitorizados através de escala visual analógica.

A técnica anestésica utilizada foi bloqueio peridural realizado com a paciente sentada, com punção em $L_{2}-L_{3}$ na linha média, utilizando agulha Tuohy 16G. Após a dose-teste de 3 $\mathrm{mL}$ de lidocaína a $2 \%$ com vasoconstritor, foi injetada bupivacaína a $0,125 \% 8 \mathrm{~mL}(10 \mathrm{mg})$ e fentanil $(100 \mu \mathrm{g})$ e logo em seguida foi introduzido cateter peridural até atingir $5 \mathrm{~cm}$ no espaço peridural. A paciente permaneceu monitorizada e recebendo oxigênio por cateter nasal a 2 L. $\mathrm{min}^{-1}$.
A parturiente referiu alívio das dores cerca de 5 minutos após o bloqueio, com mínima alteração sobre a dinâmica uterina. Após 30 minutos de analgesia, apresentava $9 \mathrm{~cm}$ de dilatação do colo uterino e dor leve a moderada na região perineal durante as contrações. Os níveis tensionais não se alteraram. A oximetria continuava oscilando durante as contrações de $88 \%$ para $80 \%$. Com uma hora de analgesia, a paciente apresentava $10 \mathrm{~cm}$ de dilatação do colo uterino e começou a ter contrações mais efetivas. Os escores de dor aumentaram e foi realizada injeção de 6,25 mg de bupivacaína a $0,125 \%$, através do cateter peridural.

A paciente foi colocada em posição ginecológica e instruídaa não realizar esforço expulsivo durante as contrações, quando apresentava níveis de oximetria com valores de $76 \%$ a $78 \%$. Após uma $1 \mathrm{~h} 30$ minutos do início da analgesia ocorreu o nascimento. O peso do recém-nascido foi de $1485 \mathrm{~g}$ e o índice de Apgar 6 e 8 no primeiro e no quinto minutos de vida, respectivamente.

Após o nascimento a paciente permaneceu estável, sem alterações hemodinâmicas ou eletrocardiográficas, porém houve aumento nos níveis da oximetria registrando $91 \%$ a $93 \%$ de $\mathrm{SpO}_{2}$.

A paciente realizou nova ecocardiografia no dia seguinte com o objetivo de revelar a via de saída do ventrículo direito que, junto às alterações previamente detectadas, evidenciou hipertrofia ventricular direita, ausência de CIA, CIV com via de saída ampla, desvio anterior do septo infundibular que gerava obstrução moderada e valvas AV normais com fração de ejeção normal. Avalva pulmonar era hipoplásica e estenótica e a aórtica ectásica com cavalgamento aórtico de $50 \%$. As artérias pulmonares estavam aparentemente desobstruídas e confluentes. As artérias coronárias não foram revisadas adequadamente. Conclusão do exame: resultados compatíveis com tetralogia de Fallot.

\section{DISCUSSÃO}

A tetralogia de Fallot é uma cardiopatia congênita caracterizada por defeito do septo ventricular, estenose pulmonar, cavalgamento aórtico sobre a comunicação interventricular e hipertrofia do ventrículo direito. Esta doença representa 15\% das cardiopatias congênitas, sendo a mais comum entre as cianóticas. Aproximadamente $15 \%$ dos pacientes com tetralogia de Fallot têm uma deleção do braço curto do cromossoma 22 como causa genética da doença e probalidade de $50 \%$ de transmissão aos descendentes ${ }^{1,2,6,7}$.

A fisiopatologia da doença depende do grau de obstrução ao fluxo de saída do ventrículo direito. Com obstrução relativamente leve a apresentação é de aumento do fluxo sangüíneo pulmonar (também chamado de "Tetralogia Rosa" ou Fallot acianótica). Ocasionalmente esta é a apresentação do adulto ${ }^{8,9}$. A maior parte das crianças, porém, apresenta-se com obstrução significativa da via de saída do ventrículo direito com conseqüente shunt direito-esquerdo e cianose.

A gestação aumenta a mortalidade e a morbidade das pacientes com tetralogia de Fallot não corrigida, principalmente naquelas com história de síncope, policitemia e hipertrofia 
ventricular direita, o que não acontece naquelas que têm sua doença corrigida cirurgicamente ${ }^{1,3,8}$.

O risco é maior quando os níveis de saturação arterial de oxigênio em repouso são menores do que $85 \%$. A diminuição da resistência vascular sistêmica, durante a gestação, e o trabalho de parto podem aumentar o shunt, agravando a acidose.

O grau de hipoxemia está diretamente relacionado à gravidade è magnitude do shunt, os quais depende de fatores fixos - grau de obstrução do ventrículo direito, grau de dextroposição da aorta, tamanho da CIV - e variáveis - RVS e RVP, obstrução infundibular, retorno venoso e contratilidade miocárdica $^{4}$.

A indicação da técnica anestésica para gestante portadora de tetralogia de Fallot não corrigida, bem como o correto manuseio de eventuais ocorrências durante o ato anestésico-cirúrgico fundamentam-se no conhecimento da gravidade das alterações a fim de determinar-se o principal mecanismo do shunt. As drogas e técnicas anestésicas podem modificar significativamente os componentes variáveis, que determinam o equilíbrio hemodinâmico desses pacientes ${ }^{1,2}$.

As técnicas regionais podem afetar este equilíbrio de acordo com o nível de bloqueio simpático produzido, que poderá aumentar o shunt, através da diminuição da RVS e, conseqüentemente diminuindo o enchimento ventricular e o débito cardíaco ${ }^{2,5}$

Princípios básicos da anestesia obstétrica devem ser aplicados, particularmente, nessas pacientes: analgesia adequada, manutenção da perfusão útero-placentária, evitando compressão aortocava e minimização do bloqueio simpático com manutenção do volume intravascular. A manutenção dos fluídos venosos deve ser cuidadosamente monitorizada a fim de evitar deficits ou excessos, provocando piora do shunt e descompensação da paciente ${ }^{2}$.

A escolha da técnica anestésica é de importância fundamental no manuseio das pacientes com tetralogia de Fallot. Quando há a possibilidade de realizar o alívio da dor com mínimas alterações hemodinâmicas, como se observa com analgesia de parto com anestesia peridural e baixas concentrações de anestésicos locais, esta se torna de grande valor no manuseio dessas pacientes.

A analgesia de parto com a técnica combinada também se mostra efetiva e segura ao permitir o uso de opióides lipofílicos por via subaracnóidea, como sufentanil, levando a um efeito analgésico mais rápido, menor bloqueio simpático, menor bloqueio motor e redução das doses de anestésico local utilizadas pelo cateter peridural ${ }^{10-12}$.

Contudo, é necessário que condições fisiológicas e obstétricas sejam observadas para um bom andamento do trabalho de parto. Condições favoráveis do colo e boa dinâmica uterina nessas pacientes, particularmente naquelas sem história de síncope, tornam-se imprescindíveis para a boa indicação da analgesia de parto.

\section{Labour Analgesia in Parturient with Uncorrected Tetralogy of Fallot. Case Report}

Florentino Fernandes Mendes, TSA, M.D.; Carlos Alberto T. Farias, M.D.; Daniel Segabinazzi, M.D.

\section{INTRODUCTION}

Tetralogy of Fallot is a cyanotic congenital heart disease characterized by right ventricular outflow obstruction, right ventricular hypertrophy, interventricular septum defect and variable aortic transposition ${ }^{1,2}$. The obstruction of right ventricular outlet is due to infundibular stenosis in many patients. At least $20 \%$ to $50 \%$ of patients also present pulmonary valve stenosis and a low percentage has some supravalvar stenotic element. Infundibular obstruction is increased in situations of increased sympathetic tone (dynamic variable) and is probably responsible for cyanosis observed in several young patients ${ }^{3}$.

The combination of right ventricular outlet obstruction and interventricular communication (IVC) results in the ejection of right ventricular non-oxygenated blood and aortic oxygenated blood. Right-left shunt determines the level of hypoxemia and, as a consequence, the severity of the disease, which varies as a function of fixed components: right ventricular obstruction level, aortic dextroposition level, IVC size - as well as variable components: systemic vascular resistance (SVR), pulmonary vascular resistance (PVR), infundibular obstruction, venous return and myocardial contractility ${ }^{4}$. Events with increased PVR, such as acidosis and increased airway pressure, should be avoided ${ }^{5}$.

The maintenance of variable components is critical for anesthetic management of patients with uncorrected disease, since they are major determinants of their hemodynamic balance.

This report aimed at describing a case of labour analgesia in uncorrected tetralogy of Fallot patient diagnosed during gestation, and at listing the cares for anesthetic management of this disease.

\section{CASE REPORT}

Patient 26 years old, $56 \mathrm{~kg}, 1.56 \mathrm{~m}, 32$ weeks and 5 days of gestational age, in labor, with uterine dynamics of 3 contractions in 10 minutes and with $4 \mathrm{~cm}$ cervical dilatation. Prenatal evaluation has revealed severe heart murmur and patient was referred to a specialized hospital were tetralogy of Fallot was diagnosed. Patient denied having previous knowledge about the disease. Patient referred mild dyspnea and cyanosis of extremities, which have worsened along gestation and were associated to not disabling precordial pain at moderate effort. 
At preanesthetic evaluation patient presented with central and extremities cyanosis and clubbed fingers, denying allergies, previous surgeries and use of medications. Fetal cardiotocography and echocardiography were normal.

Maternal echocardiography, performed at 27 weeks of gestation has revealed levocardia, aortic arch to the left, agreeing and normal AV connection, agreeing ventricular-arterial connection and normal connection mode. Patient had broad subaortic IVC as associated defect, which caused interventricular septum anterior and superior deviation, suggesting tetralogy of Fallot. Ventricles and atria had normal size, thickness and movement. ECG showed antero-septal T wave inversion.

After obstetric evaluation and decision for natural birth, monitoring consisted of pulse oximetry varying from $89 \%$ to $78 \%$ according to presence or absence of uterine dynamics, ECG with regular rhythm and $T$ wave inversion, and noninvasive blood pressure with mean level of $120 / 60 \mathrm{mmHg}$. Pain scores were monitored with visual analog scale.

Anesthetic technique was epidural block performed at $L_{2}-L_{3}$ with patient in the sitting position and using 16G Tuohy needle. After a test dose with $3 \mathrm{~mL}$ of $2 \%$ lidocaine with vasoconstrictor, $8 \mathrm{~mL}$ of $0.125 \%$ bupivacaine $(10 \mathrm{mg})$ and fentanyl $(100 \mu \mathrm{g})$ were injected and epidural catheter was inserted $5 \mathrm{~cm}$ into the epidural space. Patient remained monitored and receiving $2 \mathrm{~L}$. $\mathrm{min}^{-1}$ oxygen via nasal catheter. Patient referred pain relief approximately 5 minutes after blockade with minor uterine dynamics change. After 30 minutes patient presented $9 \mathrm{~cm}$ cervical dilatation and mild to moderate perineal pain during contractions. Pressure levels were not changed. Oximetry continued oscillating during contractions from $88 \%$ to $80 \%$. With one hour of analgesia patient presented $10 \mathrm{~cm}$ cervical dilatation and started to have more effective contractions. Pain scores increased and 6.25 $\mathrm{mg}$ of $0.125 \%$ bupivacaine were injected through the epidural catheter.

Patient was placed in the gynecological position and oriented not to push during contractions when oximetry levels were $76 \%$ to $78 \%$. Patient gave birth $1 \mathrm{~h} 30 \mathrm{~m}$ after analgesia. Newborn weight was $1486 \mathrm{~g}$ and Apgar score at one and five minutes was 6 and 8 , respectively.

After delivery patient remained stable, with no hemodynamic or ECG changes, however with increased oximetry levels of $91 \%$ to $93 \%$.

A new echography was performed the next day aiming at finding right ventricular outflow which, together with previously detected changes, has evidenced right ventricular hypertrophy, lack of IAC, IVC with broad outflow, anterior infundibular septum shift generating moderate obstruction and normal AV valves with normal ejection fraction. Pulmonary valve was hypoplastic and stenotic and aortic valve was ectatic with aortic $50 \%$ riding. Pulmonary arteries seemed to be unobstructed and confluent. Coronary arteries were not adequately reviewed. Test conclusion was: results compatible with tetralogy of Fallot.

\section{DISCUSSION}

Tetralogy of Fallot is a congenital heart disease characterized by ventricular septum defect, pulmonar stenosis, aortic riding on interventricular communication and right ventricular hypertrophy. This disease represents $15 \%$ of congenital cardiopathies and is the most common among cyanotic heart diseases. Approximately $15 \%$ of tetralogy of Fallot patients have a deletion of the short arm of chromosome 22 as the genetic cause of the disease and there is $50 \%$ probability of transmission to offsprings ${ }^{1,2,6,7}$.

Disease pathophysiology depends on the level of right ventricular outflow obstruction. With relatively mild obstruction, presentation is increased pulmonary blood flow (also called Rose Tetralogy or acyanotic Fallot). Occasionally this is the adult presentation ${ }^{8,9}$. Most children, however, have significant right ventricular outflow obstruction with consequent right-left shunt and cyanosis.

Gestation increases mortality and morbidity rates of uncorrected tetralogy of Fallot patients, especially those with history of syncope, polycythemia and right ventricular hypertrophy, what is not true for those surgically corrected ${ }^{1,3,8}$.

Risk is increased when arterial oxygen saturation levels at rest are below $85 \%$. Decreased systemic vascular resistance during gestation and labour may increase shunt and worsen acidosis.

The level of hypoxemia is a direct function of shunt severity and magnitude, which depend on fixed factors -right ventricular obstruction level, aortic dextroposition level, IVC size and variable factors - SVR and PVR, infundibular obstruction, venous return and myocardial contractility ${ }^{4}$.

The indication of the anesthetic technique for uncorrected tetralogy of Fallot patients, as well the adequate management of possible intraoperative events, are based on the understanding of the severity of the disease to determine major shunt mechanism. Anesthetic drugs and techniques may significantly change variable components determining the hemodynamic balance of such patients ${ }^{1,2}$.

Regional techniques may affect this balance according to the level of sympathetic blockade, which may increase shunt by decreasing SVR and, as a consequence, decrease ventricular filling and cardiac output ${ }^{2,5}$.

Basic obstetric anesthesia principles should be particularly applied to these patients: adequate analgesia, maintenance of uterine-placental perfusion preventing aortocaval compression and minimization of sympathetic block by maintaining intravascular volume. Intravenous fluids should be carefully monitored to prevent deficits or excesses, leading to shunt worsening and patients decompensation ${ }^{2}$.

The choice of the anesthetic technique is critical to manage tetralogy of Fallot patients. When pain may be relieved with minor hemodynamic changes, as it is the case with labour epidural analgesia and low local anesthetics concentrations, this would be valuable for the management of these patients. Combined labour analgesia is also effective and safe because it allows the use of subarachnoid lipophylic opioids, such as sufentanil, leading to faster analgesic effect, lower 
sympathetic and motor block, in addition to lower local anesthetics via epidural catheter ${ }^{10-12}$.

However, physiological and obstetric conditions have to be observed for good labour outcome. Favorable cervical conditions and good uterine dynamics in these patients, especially those with no history of syncope, are indispensable for adequate indication of labour analgesia.

\section{REFERÊNCIAS - REFERENCES}

01. Presbitero P, Somerville J, Stone S et al - Pregnancy in cyanotic congenital heart disease. Outcome of mother and fetus. Circulation 1994;89:2673-2676.

02. Kuczkowski KM - Labor analgesia for the parturient with cardiac disease: what does an obstetrician need to know? Acta Obstet Gynecol Scand, 2004;83:223-233.

03. Carvalho JCA, Matias RS, Siaulys MM et al - Anestesia para cesárea em portadoras de tetralogia de Fallot corrigida cirurgicamente. Rev Bras Anestesiol, 1992;42:429-431.

04. Brickner ME, Hillis LD, Lange RA - Congenital heart disease in adults. Second of two parts. N Engl J Med, 2000;342:334-342.

05. Warner MA, Lunn RJ, O'Leary PW et al - Outcomes of noncardiac surgical procedures in children and adults with congenital heart disease. Mayo Clin Proc, 1998;73:728-734.

06. Payne RM, Johnson MC, Grant JW et al - Toward a molecular understanding of congenital heart disease. Circulation, 1995; $91: 494-504$.

07. Galli KK, Myers LB, Nicolson SC - Anesthesia for adult patients with congenital heart disease undergoing noncardiac surgery. Int Anesthesiol Clin, 2001;39:43-71.

08. Pozzi M, Trivedi DB, Kitchiner D et al - Tetralogy of Fallot: what operation, at which age. Eur J Cardiothorac Surg, 2000;17: 631-636.

09. Sohn S, Lee YT - Outcome of adults with repaired tetralogy of Fallot. J Korean Med Sci, 2000;15:37-43.

10. Harsten A, Gillberg L, Hakansson L et al - Intrathecal sufentanil compared with epidural bupivacaine analgesia in labour. Eur $\mathrm{J}$ Anaesthesiol, 1997;14:642-645.
11. Arkoosh VA, Cooper M, Norris MC et al - Intrathecal sufentanil dose response in nulliparous patients. Anesthesiology, 1998;89:364-370.

12. Nageotte MP, Larson D, Rumney PJ et al - Epidural analgesia compared with combined spinal-epidural analgesia during labor in nulliparous women. N Engl J Med, 1997;337:1715-1719.

\section{RESUMEN}

Mendes FF, Farias CAT, Segabinazzi D - Analgesia de Parto en Paciente con Tetralogía de Fallot No Corregida. Relato de Caso

JUSTIFICATIVA Y OBJETIVOS: Aunque la tetralogía de Fallot sea la más común de las cardiopatías congénitas cianóticas, las publicaciones nacionales, relacionando esa enfermedad con la práctica anestésica son escasas. El objetivo de este relato es presentar un caso de analgesia de parto en paciente portadora de tetralogía de Fallot no corregida y diagnosticada durante la gestación.

RELATO DEL CASO: Paciente con 26 años, $56 \mathrm{~kg}, 1,56 \mathrm{~m}$, edad gestacional 32 semanas y 5 días, con diagnóstico de tetralogía de Fallot realizado durante la gestación. Internó en trabajo de parto. La conducta obstétrica fue la de parto vía baja, siendo realizada analgesia de parto a través de bloqueo peridural con bupivacaína a 0,125\% y fentanil $(100 \mu \mathrm{g})$ y colocación de catéter peridural. Después de 1 h30 minutos del inicio de la analgesia, ocurrió el nacimiento. El peso del recién nacido fue $1485 \mathrm{~g}$ y el índice de Apgar 6 y 8 en el primero y en el quinto minutos, respectivamente. La paciente permaneció estable $y$ sin alteraciones hemodinámicas y/o electrocardiográficas.

CONCLUSIONES: La elección de la técnica anestésica es de fundamental importancia en el manoseo de las pacientes con tetralogía de Fallot no corregidas. Condiciones favorables del cuello y buena dinámica uterina, particularmente en aquellas pacientes sin historia de síncope, se vuelven imprescindibles para una buena indicación de la analgesia de parto. 